$\underline{\text { ARTICOLE }}$

\title{
REMEDIUL ÎMPOTRIVA UNUI FINAL FATIDIC SUBIT: SUSPENDAREA ACTULUI ADMINISTRATIV-FISCAL
}

\section{A REMEDY AGAINST A SUDDEN FATIDICAL END: THE SUSPENSION OF THE ADMINISTRATIVE-FISCAL ACT}

DOI:10.24193/SUBBiur.63(2018).2.3

Published Online: 2018-06-29

Published Print: 2018-06-29

Septimiu PUȚ*

\begin{abstract}
For safeguarding the rights of the Romanian tax debtor, the use of the procedural means provided by the positive law, mainly the provisions of art. 14 and art. 15 of the Romanian lawn. 554/ 2004, is crucial. In essence, the suspension of the administrative-fiscal acts signifies the legal operation of temporarily suspending their effects. Therefore, knowing its particularities is especially important for the tax debtor. This paper addresses the following question: When thesuspension of theexecution of the administrative-fiscal act has already been ruled by the court, on the basis of the provisions of art. 14 of the law 554/2004, could an application for suspension of the execution of the judicial act be demanded on the basis of the provision of art. 15? From the tax debtor perspective, the objective of this demand would aim at extending the suspensive effect of enforcement beyond the moment on with the court had ruled on the merits of the dispute. In our opinion, there is no imperative impediment. Furthermore, a new bail should not be required from the tax debtor.
\end{abstract}

Rezumat: Utilizarea resorturilor procedurale prevăzute de dreptul pozitiv, şi anume, dispozițiile art. 14 și 15 ale Legii nr. 554/2004 a contenciosului administrativ, devine imperativă pentru salvgardarea drepturilor subiective ale debitorului fiscal. În esență, suspendarea actelor administrativ-fiscale reprezintă operațiunea juridică de întrerupere temporară a efectelor acestora, iar cunoașterea specificului acesteia este deosebit de importantă. Problema care se pune este aceea de a cunoaște dacă este admisibilă o cerere de suspendare a efectelor actului administrativ-fiscal în baza dispozițiilor art. 15, când suspendarea executării actului a fost deja pronunțată în baza dispozițiilor art. 14, cu finalitatea prelungirii efectelor suspensive de executare 
dincolo de momentul pronunțării instanței pe fondul litigiului? În opinia noastră, nu există niciun impediment de ordin imperativ și nici condiția plății din nou a unei cauțiuni.

Keywords: tax law, suspension of the administrative-fiscal act, legal effects.

Cuvinte-cheie: drept fiscal, suspendarea actului administrativ-fiscal, efecte juridice.

\section{Contextualizare}

Într-o societate în care organele fiscale acţionează preponderent distructiv, impunând obligații fiscale suplimentare cu obstinență, contribuabilul trebuie să utilizeze cele mai inspirate mecanisme pentru a înlătura efectele juridice nefaste ale actelor administrativ-fiscale nelegale. Sigur, finalitatea este aceea a anulării acestor acte administrativ-fiscale, doar că până în momentul în care o instanță ajunge să se pronunțe cu privire la fondul litigiului, există riscuri reale de executare a unui act administrativ-fiscal, chiar nelegal fiind, și de paralizare a activității desfăşurate de către contribuabil.

Din cauza regimului specific, contribuabilii persoanejuridice sunt cei mai expuși efectelor imediate ale actului administrativ-fiscal. De la înființare și până la radiere, persoanele juridice sunt supuse unor multiple formalități de publicitate, în comparație cu persoanele fizice în privința cărora se poate constata o volatilitate a informațiilor pe care organele fiscale le pot utiliza în ipoteza emiterii unui titlu de creanță și a punerii în executare a acestuia.

Odată cu comunicarea deciziei de impunere, contribuabilul se transformă în debitor fiscal - titularul unei obligații de plată corelativă unui drept de creanță fiscală ${ }^{1}$, fiind expus acțiunilor de executare ale organului fiscal. Acest tip de relație stat - particular este cu atât mai încordată, cu cât în raportul juridic se devoalează perspective eterogene asupra instituțiilor fiscale incidente.

Prima etapă în procedura fiscală o reprezintă faza administrativ-jurisdicțională activată prin formularea contestației fiscale. Abia după soluționarea contestației fiscale, particularul poate contesta actul administrativ-fiscal și decizia de soluționare a contestației în fața instanței de contencios administrativ și fiscal competente. De regulă, între momentul formulării și cel al soluționării contestației fiscale trece mai mult timp. De regulă, între momentul înregistrării 
contestației fiscale la organul emitent și comunicarea deciziei de soluționare de către organul competent care activează efectiv dreptul de a învesti instanța de contencios administrativ şi fiscal cu o cerere de anulare a actului administrativfiscal nelegal, trec mai multe luni.

În procedura de soluționare a contestației fiscale nu există un termen de tranşare a acesteia, astfel că se prezumă că trebuie avut în vedere termenul general de soluționare a cererilor contribuabililor. În acord cu dispozițiile art. 77 alin. (1) C.pr.fisc.: „Cererile depuse de către contribuabil/plătitor la organul fiscal se soluționează de către acesta în termen de 45 de zile de la înregistrare."

Practic, în absența vreunei sancțiuni, la fel ca în cazul nemotivării hotărârilor judecătorești, organul fiscal nu mai este motivat să se încadreze în termenul indicat și temporizează, de multe ori, excesiv soluționarea contestației fiscale.

Totuși, potrivit art. 281 alin. (5) C.pr.fisc.: „În situația nesoluționării contestației în termen de 6 luni de la data depunerii contestației, contestatorul se poate adresa, pentru anularea actului, instanței de contencios administrativ competente potrivit Legii nr. 554/2004, cu modificările și completările ulterioare." Gândită ca un remediu pentru contribuabili, dispoziția sus-menționată a devenit, în fapt, un remediu pentru organul fiscal care sub pretextul multitudinii contestațiilor fiscale, nu mai soluționează contestația fiscală, iar după 6 luni, în situația formalizării judiciare a particularului, ajunge să se dezinvestească, iar nu să soluționeze contestația.

În ipoteza în care în paralel cu inspecția fiscală, s-a dispus începerea urmăririi penale, direcțiile de soluționare a contestațiilor preferă soluția oomodă a suspendării soluționării contestațiilor. $O$ asemenea măsură este luată sub pretextul că organul care a efectuat activitatea de control a sesizat organele penale cu privire la existența indiciilor săvârşirii unei infracțiuni în legătură cu mijloacele de probă privind stabilirea bazei de impozitare și a cărei constatare ar avea o înrâurire hotărâtoare asupra soluției ce urmează să fie dată în procedură administrativă.

În contextul lentorii cvasi-instituționalizate, până la soluționarea contestației, înregistrarea cererii de chemare în judecată, soluționarea acesteia și inexorabil a unui potențial recurs promovat de către partea perdantă, contribuabilul este nu doar executat, ci uneori chiar falimentat. Tocmai de aceea, utilizarea resorturilor procedurale de temporizare prevăzute de dreptul pozitiv - dispozițiile art. 14 și 15 ale Legii nr. 554/2004 a contenciosului administrativ, 
devine imperativă pentru salvgardarea drepturilor subiective ale debitorului fiscal. În esență, „suspendarea actelor juridice reprezintă operația juridică de întrerupere vremelnică a efectelor acestora."2

\section{Suspendarea judiciară. Condițiile suspendării}

După cum s-a arătat în doctrina de drept administrativ, „actele administrative sunt executorii din oficiu și prin ele însele, adică nu necesită intervenția unui alt organ pentru a le învesti cu formulă executorie. Datorită acestui specific, devine necesară suspendarea lor atunci când sunt contestate din punct de vedere al legalității și când prin executare ar putea provoca o pagubă persoanelor fizice sau juridice protejate prin instituția contenciosului administrativ"3.

În acelaşi sens, „suspendarea este operațiunea juridică ce determină încetarea temporară a efectelor actelor administrative. Ea este dispusă, de regulă, atunci când există un dubiu asupra legalității sau oportunității unui act"4 . Suspendarea executării actului administrativ reprezintă o situație de excepție ${ }^{5}$ în condițiile în care acesta „se bucură de prezumția de legalitate care, la rândul său, se bazează pe prezumția de autenticitate (actul emană de la cine se spune că emană) şi de prezumția de veridicitate (actul exprimă ceea ce în mod real a decis organul emitent) ${ }^{6}$.

Totodată, s-a mai arătat că pentru a se ajunge la soluția suspendării actului administrativ de către instanța de contencios, „trebuie îndeplinită o condiție de procedură: petentul să fi formulat deja plângerea prealabilă în temeiul art. 7 din lege (în cazul suspendării întemeiate pe dispozițiile art. 14, respectiv să fi înregistrat la instanță acțiunea în anularea actului (în cazul celei întemeiate pe dispozițiile art. 15, respectiv o dublă condiție de fond: să existe un caz bine justificat (existența unei îndoieli serioase asupra legalității actului atacat - aparența de ilegalitate), respectiv să existe o pagubă iminentă. 7 .

Condițiile legale pentru admiterea cererii de suspendare în contencios fiscal, fundamentate pe dispozițiile art. 14 din L: 554/2004 sunt: 1) declanșarea procedurii administrative prealabile, prin formularea unei contestaţii fiscale în materie; 2) existența unui „caz bine justificat”; 3) existența unei „pagubeiminente" și 4) plata cauțiunii predeterminate de legea procedural-fiscală. Având în 
vedere că înregistrarea contestației fiscale drept condiție procedural-formală nu reclamă o atenție specială, ne vom concentra asupra celorlalte condiții care au suscitat numeroase discuții și dispute doctrinare și jurisprudențiale.

\subsection{Cazul bine justificat}

Sintagma „caz bine justificat” reprezintă o expresie normativă care întreține dubiul propriei sfere de aplicare. Astfel, i-a revenit practicii judiciare misiunea de a configura în plan concret domeniul de aplicare a acestei sintagme normative. Înalta Curte de Casație și Justiție a reținut existența „cazului bine justificat” prin raportare la exigențele principiului legalității în sensul că orice dubiu care atentează la prezumția de legalitate a actului administrativ poate constitui un temei serios în temporizarea caracterului executoriu al actului administrativ.

Printr-o decizie de referință, instanța supremă statuează că „pentru conturarea cazului temeinic justificat care să impună suspendarea unui act administrativ, instanța nu trebuie să procedeze la analizarea criticilor de nelegalitate pe care se întemeiază însăşi cererea de anulare a actului administrativ, ci trebuie să-şi limiteze verificarea doar la acele împrejurări vădite de fapt și/sau dedrept care au capacitatea să producă o îndoială serioasă asupra prezumției de legalitate de care se bucură un act administrativ." prejurărilor de fapt sau de drept a căror proiecție asupra actului administrativ poate produce o îndoială serioasă cu privirela legalitatea unui act administrativ, au fost reținute, în jurisprudența instanței supreme, și următoarele: emiterea unui act administrativ de către un organ necompetent, emiterea unui act administrativ în temeiul unor dispoziții legale declarate neconstituționale, nemotivarea actului administrativ, modificarea importantă a actului administrativ în calea recursului administrativ.

La nivelul Curții de Apel Cluj s-a considerat că analiza unui asemenea caz bine justificat ar trebui să se facă prin raportare la valențele principiului legalității, care se impune respectului autorităților publice: existența unei baze legale; obligația de a respecta regulile care vizează activitatea administrației; obligația de a respecta legile generale. Curtea de Apel Cluj nu a negat existența prezumției de legalitate a oricărui act administrativ fiscal, dar a subliniat faptul că dispozițiile legii contenciosului administrativ permit adoptarea unei 
măsuri de conservare justificate în situațiile în care executarea actului cu privire la care există o îndoială serioasă ar produce o pagubă iminentă. În acest fel se asigură un echilibru în procesul executării actelor administrative și se asigură respectarea garanțiilor de echitate pentru cetățeni ${ }^{9}$. Aceeași instanță a precizat, cu privire la o teză de apărare clasică a organelor fiscale, că nu poate fi acceptată ideea potrivit căreia suspendarea s-ar putea dispune doar atunci când există un motiv de nulitate absolută expresă a unui act administrativ fiscal (art. 46 V. C.pr.fisc., respectiv art. 49 N. C.pr.fisc. ${ }^{10}$ ), intenția legiuitorului fiind aceea de a pune la dispoziția cetățeanului mijloace eficace prin care să-și protejeze provizoriu drepturile şi interesele sale legitime ${ }^{11}$.

De dată recentă, Curtea de Apel a statuat că: deși în procedura de soluționare a unei cereri de suspendare instanța trebuie să se abțină de la aprecieri de substanță cu privire la legalitatea actului administrativ a cărei suspendare se cere, Curtea observă că criticile de nelegalitate invocate de către reclamantă, în cererea introductivă, sunt pertinente și creează o îndoială serioasă în privința legalității actului administrativ în cauză. Împrejurările evocate de reclamantă referitoare la faptul că echipa de inspecție fiscală nu a analizat actele vizând operațiunile derulate prin raportare la înregistrările contabile, nu a recunoscut dreptul de deducere și implicit au fost greșit determinate obligațiile fiscale, pot fi apreciate ca un caz bine justificat, o aparență de nelegalitate dată de modalitatea de emitere a actului și nedeterminarea obligației în raport de situația reală. Analiza incompletă a elementelor concrete şi edificatoare vizând operațiunile desfăşurate reprezintă un motiv suficient pentru a pune la îndoială legalitatea exercitării dreptului de apreciere al organului administrativ fiscal. De asemenea, trebuie avute în vedere și apărările făcute de partea reclamantă referitoare la documentele suplimentare pe care le deține pentru o eventuală exercitare a dreptului de deducere al TVA, în afara facturilor fiscale ${ }^{12}$. Prin urmare, avem de a face cu un „caz bine justificat” și dacă a fost nesocotit dreptul la apărare al contribuabilului reconfigurat jurisprudențial de către CJUE prin hotărârea din afacerea Ispas C-298/ $16^{13}$.

Printr-o altă hotărâre recentă, bine fundamentată și ancorată ontologic, Curtea de Apel Cluj a statuat că: ,în procesul executării din oficiu a actelor administrative trebuie asigurat un anumit echilibru, precum şi anumite garanții de echitate pentru particulari, întrucât acțiunile autorităților publice nu pot fi discreționare, iar legea trebuie să furnizeze individului o protecție 
adecvată împotriva arbitrariului. Tocmai de aceea, suspendarea executării actelor administrative trebuie considerată ca fiind în realitate un eficient instrument procedural aflat la îndemâna autorității emitente sau a instanței de judecată pentru a asigura respectarea principiului legalității, fiind echitabil ca atâta timp cât autoritatea public sau judecătorul se află în proces de evaluare, acestea să nu-şi producă efectele asupra celor vizați”"14.

În opinia noastră, ar trebui considerate motive serioase de fundamentare a condiției cazului bine justificat în materie fiscală: necompetența organului fiscal, nemotivarea actului administrativ-fiscal, încălcarea dreptului la apărare, depăşirea duratei legale de efectuarea a inspecției fiscale sau încălcarea regulilor imperative de desfăşurare a inspecției fiscale, lipsa audierii contribuabilului s.a.

\subsection{Paguba iminentă}

Condiției pagubei iminente este îndeplinită, potrivit dispoziției legale care o reglementează, în situația în care executarea actului administrativ ar produce un prejudiciu greu sau imposibil de înlăturat prin anularea actului. Dispozițiile legale incidente conferă un sens larg noțiunii de „pagubă iminentă”, avându-se în vedere nu numai „prejudiciul material viitor, dar previzibil cu evidență”, dar și „perturbarea previzibilă gravă a funcţionării unei societăți sau a unui serviciu public". Astfel, în cazul cel mai frecvent al persoanelor juridice care nu sunt autorități publice și care nu prestează un serviciu public, paguba iminentă este reprezentată de un prejudiciu material viitor, care se va produce cu certitudine. Așadar criteriile care configurează prejudiciul sunt următoarele: prejudiciul trebuie să fie unul material, prejudiciul trebuie să fie cert că se va produce, chiar dacă este unul viitor și, prin urmare, să fie previzibil15.

Condiția pagubei iminente trebuie analizată și prin perspectiva efectelor produse de actele administrativ-fiscale. În acord cu profilul contenciosului fiscal român, actele administrativ-fiscale produc efectejuridice cel mai devreme în 30 de zile de la data emiterii lor (fie în 5 , fie în 20 ale lunii următoare comunicării) ${ }^{16}$. Astfel, executarea silită este iminentă, fără ca anterior reclamantul să fi avut posibilitatea de a solicita instanței să se pronunțe pe fondul solicitării de anulare a actului administrativ-fiscal. În acest sens, instanța supremă a apreciat că executarea silită a bunurilor imobile şi mobile ale debi- 
torului, care nu ar mai putea fi întoarsă, întrunește condiția pagubei iminente ${ }^{17}$. Un alt element care poate contribui la configurarea condiției „pagubei iminente" îl reprezintă onestitatea comportamentului fiscal al contribuabilului, alături de impactul social pe care executarea actului administrativfiscal îl poate genera pentru persoanele juridice în ceea ce privește onorarea obligațiilor din contractele de muncă încheiate cu angajații. Riscul concedierii salariaţilor trebuie apreciat în concret și corelat cu alte elemente de fapt. Apoi, poprirea conturilor bancare ale persoanei juridice ca urmare a executării actului administrativ-fiscal punecontribuabilul înimposibilitatea de a-și mai onora contracte aflate în derulare: cu furnizorii, unități bancare, persoane juridice de drept public.

Curtea de Apel Cluj statuează, în una dintre hotărârile recent pronunțate, că „In ceea ce privește cerința iminenței producerii unui prejudiciu, Curtea apreciază că poate fi reținută ca fiind îndeplinită în contextul în care o executare ar atrage o blocare a activității, cu consecința neonorării contractelor, stare ce ar genera imposibilitatea plății salariilor determinând astfel și o eventuală consecință de pierdere a salariaților."18

Cererea de suspendare a actului administrativ fiscal vizează acordarea unei protecții jurisdicționale provizorii a particularului, până la momentul în care o instanță va dezbate pe fond realitatea și cuantumul obligațiilor fiscale. Aceste elemente nu prejudiciază organele fiscale, singura necunoscută, în ipoteza menținerii actului administrativ-fiscal, fiind aceea a momentului colectării creanței fiscale.

În pluriversul juridic actual trebuie avută în vedere și Recomandarea nr. r(89)8, din 13 septembrie 1989, a Comitetului de miniștri către statele membre, privind protecția provizorie acordată de instanță pe probleme administrative care statuează în esență următoarele:

„I Atunci când o instanță este sesizată cu o contestație referitoare la un act administrativ, iar instanța nu a pronunțat încă o decizie, solicitantul poate cere aceleiași instanțe sau unei alte instanțe competente să ia măsuri de protecție provizorie împotriva actului administrativ. Persoana în cauză trebuie să aibă acelaşi drept de a solicita unei instanțe competente să ia măsuri de protecție provizorie, înainte de contestarea actului în conformitate cu primul sub-paragraf, în caz de urgență sau atunci când o plângere administrativă, care nu cuprinde în sine niciun efect suspensiv, a fost depusă împotriva actului administrativ și nu a fost încă soluționată. 
II În decizia privind acordarea protecției provizorii solicitantului, instanța trebuie să ia în considerare toți factorii relevanți și interesele. Măsuri de protecție provizorii pot fi acordate, în special, în cazul în care executarea actului administrativ este susceptibilă de a provoca daune severe, care ar putea fi remediate cu dificultate și dacă există un caz prima-facieîmpotriva valabilității actului."

\subsection{Cauțiunea}

Consemnarea cauțiunii este o condiție „tehnică” obligatorie. Finalitatea instituirii obligației de indisponibilizare a unei sume de bani, expresie a unui formalism suplimentar accentuat, este aceea de a descuraja cererile neserioase, vexatorii ale diferiților contribuabili disperați.

Potrivit art. 215 alin. (2) V. C.proc.fisc., constituirea unei cauțiuni putea să se ridice până la $20 \%$ din valoarea sumei contestate. Fixarea unei cauțiuni apropiate de limita superioară de $20 \%$ punea în mod serios problema respectării dreptului subiectiv fundamental de acces la un tribunal.

Actualmente, cauțiunea a fost recalibrată prin dispozițiile N. C.pr.fisc. şi aşezată în limite relativ rezonabile. Potrivit art. 278 alin. (2) N. C.pr.fisc., cauțiunea va fi stabilită în funcție de valoarea contestată și poate ajunge de la 10\% pentru valori de până la 10.000 lei, până la 14.500 lei plus 0,1\% pentru valori care depășesc 1.00o.ooo lei.

\section{Este admisibilă formularea unei cereri de suspendare în-} temeiată pe dispozițiile art. 15, când executarea actului administrativ-fiscal este suspendată pe dispozițiile art. 14, cu sau fără consemnarea unei cauțiuni?

Răspunsul la această întrebare a fost oferit jurisprudențial. Astfel, Curtea de Apel Cluj a statuat printr-o sentință civilă recentă că: „având în vedere că la primul termen de judecată, reprezentantul reclamantei a arătat că nu a consemnat cauțiunea fixată de către instanță, întrucât aceasta a fost depusă în dosarul nr. x/2016, având ca obiect cererea de suspendare a executării aceluiaşi act administrativ, formulată în baza art. 14 din L: 554/2004, care a fost admisă, Curtea a pus în discuția părților existenta autorității de 
lucru judecat, având în vedere că în ambele dosare se solicită suspendarea executării aceluiași act administrativ, aceasta și în contextul dispozițiilor art. 15 alin. (4) din L: 554/2004. Având însă în vedere efectele în timp pe care le poate produce suspendarea dispusă în condițiile art. 14 și art. 15 din L: 554/2004, Curtea apreciază că identitatea de obiect între cele două cauze poate fi si doar parțială, neputându-se reține existența autorității de lucru judecat. Cât privește dreptul judecătorului de a invoca autoritatea de lucru judecat, acesta este prevăzut expres de dispozițiile art. 22 alin. (2) din Codul de procedură civilă, chiar și în ipoteza în care părțile se împotrivesc sau nu au formulat o astfel de apărare. În condițiile în care instanței i s-a adus la cunoștință existența celuilalt proces doar la primul termen de judecată, evident autoritatea de lucru judecat a fost pusă în discuția părților în ședința de la acel termen, la care reprezentantul ales al părții a lipsit, fiind prezent în substituirea acestuia un alt apărător, criticile din cuprinsul concluziilor scrise fiind vădit neîntemeiate sub acest aspect.”19

Într-o altă cauză, Curtea de Apel Cluj s-a referit la necesitatea consemnării cauțiunii în momentul formulării cererii de suspendare în baza dispozițiilor art. 15, precizând că: „atâta timp cât art. 278 alin. (2) din Codul de procedură fiscală se referă la suspendarea dispusă în temeiul Legii nr. 554/2004, nu există niciun motiv pentru a considera că aceasta se referă doar la suspendarea dispusă în temeiul art. 14 din această lege, fără să se refere și la cea menționată de art. 15. Reclamanta a mai arătat că a achitat cauțiunea în cadrul cererii de suspendare formulate și respinse anterior în temeiul art. 14 din L: 554/2004 și că nu ar mai fi necesară achitarea unei cauțiuni diferite. $\mathrm{O}$ astfel de interpretare nu poate să fie primită din următoarele motive. În primul rând, niciunde în cadrul art. 14, [sau] 15 din L: 554/ 2004 sau al art. 278 din Codul de procedură fiscală nu se prevede că nu ar mai fi necesară achitarea cauțiunii în cazul formulării unei a doua cereri de suspendare. Atâta timp cât legea nu distinge, înseamnă că achitarea cauțiunii este necesară în cazul fiecărei cereri de suspendare formulate.

Pe de altă parte, atâta în măsura în care soluția definitivă în situația cererii formulateîn temeiul art. 14 ar fi cea de respingere a cererii de suspendare, ar fi posibil ca reclamanta să obțină restituirea cauțiunii achitate. Prin urmare, dacă într-o cerere separată (cum este cea formulată în prezentul dosar) s-ar dispune suspendarea actului administrativ atacat, ar fi, oricum, posibil ca reclamantului să i se restituie cauțiunea achitată anterior. Astfel, dacă 
pentru cea de-a doua cerere de suspendare nu s-ar achita o cauțiune separată, s-ar ajunge la situația ca actul în cauză să fie suspendat fără să existe nicio cauțiune achitată, ceea ce, în mod cert, este contrar și literei și spiritului legii. În consecință, instanța va respinge cererea de suspendare formulată, constatând că, deși reclamanta avea obligația să achite cauțiunea prevăzută de lege, nu a făcut acest lucru."20

În opinia noastră, soluțiile de respingere a cererilor de suspendare fundamentate pe dispozițiile art. 15 din legea contenciosului administrativ, cu motivările mai sus-rezumate, sunt eronate, atât din perspectiva obligativității reconsemnării cauțiunii în ipoteza formulării unei noi cereri de suspendare, cât și din perspectiva existenței autorității de lucru judecat, chiar parțiale. Această concluzie reiese din dreptul pozitiv procedural fiscal și din regimul juridic al celor două tipuri de suspendare a actului administrativfiscal pe care le vom analiza în cele ce urmează.

\section{Compatibilizarea cererii de suspendare fundamentate pe dispozițiile art. 15 cu cererea de suspendare întemeiată pe pre- vederile art. 14 din L: 554/2004}

Diferențele de regim juridic între cererea de suspendare întemeiată pe dispozițiile art. 14 și cererea de suspendare bazată pe dispozițiile art. 15 sunt punctuale, dar totuși semnificative.

Din perspectiva momentului la care se poate solicita suspendarea actului administrativ-fiscal, cererea fundamentată pe dispozițiile art. 14 se poate formula după înregistrarea contestației fiscale, iar cererea fundamentată pe dispozițiile art. 15 după soluționarea contestației fiscale sau după minim 6 luni de la înregistrarea contestației fiscale.

Condițiile generale pe care le implică cererea fundamentată pe dispozițiile art. 14 sunt: formularea și înregistrarea contestației fiscale la organul emitent al actului administrativ-fiscal, plata cauțiunii în cuantumul prevăzut de art. 278 alin. (2) din N. C.pr.fisc., existența unui caz bine justificat și necesitatea prevenirii pagubei iminente. Cererea fundamentată pe dispozițiile art. 15 presupune: soluționarea contestației fiscale (finalizarea procedurii prealabile obligatorii) sau depăşirea termenului legal de soluționare a contestației fiscale de 6 luni, plata cauțiunii ${ }^{21}$, existența unui caz bine justificat și necesitatea prevenirii pagubei iminente. 
În ipoteza prevăzută de art. 14, suspendarea actului administrativ-fiscal durează de la momentul pronunțării hotărârii până la data soluționării fondului litigiului (de către prima instanță de judecată), iar în ipoteza prevăzută de art. 15 suspendarea actului administrativ-fiscal durează de la momentul pronunțării instanței de fond și până la momentul pronunțării instanței de recurs. În fine, efectele juridice pe care suspendarea actului administrativ-fiscal le produce sunt aceleași în ambele cazuri și anume temporizarea punerii în executare a actului administrativ fiscal, pe o anumită perioadă de timp.

Operând suspendarea efectelor actului-administrativ fiscal în sine, pe durata perioadei de suspendare, obligațiile fiscale accesorii încetează să mai curgă. Sigur că o eventuală admitere a recursului organului fiscal împotriva sentinței civile de admitere a cererii de suspendare are drept consecință calcularea accesoriilor fiscale pentru întreaga perioadă22 . Aceeaşi soluție a calculării accesoriilor va fi validată și în măsura în care s-ar dispune admiterea recursului împotriva sentinței de admitere a cererii de chemare în judecată în contencios fiscal și de desființare a deciziei de soluționare a contestației și a actului administrativ-fiscal, considerându-se că actul administrativ-fiscal a fost activ tot timpul.

Potrivit conținutului art. 278 alin. (6) C.pr.fisc. ${ }^{23}$,„̂n cazul în care s-a formulat o cerere de suspendare a actului administrativ fiscal în temeiul art. 14 din Legea contenciosului administrativ nr. 554/2004, cu modificările și completările ulterioare, iar cauțiunea prevăzută la alin. (2) este deja consemnată la dispoziția instanței, nu este necesară consemnarea unei noi cauțiuni în situația în care se solicită suspendarea actului administrativ fiscal în temeiul art. 15 din L: 554/2004, cu modificările și completările ulterioare, cu condiția ca, la data pronunțării asupra cererii de suspendare în temeiul art. 15 din L: 554/2004, cauțiunea să fie consemnată efectiv la dispoziția instanței24. Astfel, deși cele două hotărâri judecătorești, anterior citate, au fost pronunțate la data de 29.09.2017, niciuna nu a ținut cont de modificările normative aduse prin OG: 30/2017 care vizau norme de procedură şi care erau active și aplicabile la data soluționării cererilor de suspendare.

$\mathrm{Cu}$ toate acestea, dacă s-a obținut suspendarea actului administrativfiscal în temeiul dispozițiilor art. 14 din L: 554/2014, pentru a se menține efectul acestei suspendări, contribuabilul trebuie să înregistreze cererea de chemare în judecată în termen de 60 de zile de la comunicarea deciziei de 
soluționare, chiar dacă beneficiază de termenul lax de 6 luni pentru a se formaliza judiciar. Art. 278 alin. (5) C.pr.fisc. prevede: „Suspendarea executării actului administrativ fiscal dispusă potrivit art. 14 din L: 554/2004, cu modificările și completările ulterioare, încetează de drept și fără nicio formalitate dacă acțiunea în anularea actului administrativ fiscal nu a fost introdusă în termen de 60 de zile de la data comunicării deciziei de soluționare a contestaţiei."

Odată pronunțată suspendarea fundamentată pe dispozițiile art. 14, instanța învestită cu soluționarea unei cereri de suspendare în baza art. 15 ar urma să preia considerentele hotărârii iniţiale în ipoteza în care nu au survenit modificări în planul condițiilor legal prevăzute și să acorde beneficiul suspendării actului administrativ-fiscal dincolo de momentul pronunțării pe fondul litigiului, prin sentință ${ }^{25}$.

\section{Concluzii}

Privite ca elemente colaterale în angrenajul contenciosului fiscal pozitiv, mecanismele procedurale de suspendare a executării actului administrativ-fiscal reprezintă remedii utile pentru particularul vexat printr-un act administrativ nelegal emis de organul fiscal. Pentru a putea utiliza adecvat aceste remedii procedurale de temporizare a efectelor juridice specifice actului administrativ, care devin vitaleîn contextul casant actual, particularul trebuie să înțeleagă resortul și specificul cererilor fundamentate pe dispozițiile art. 14, respectiv ale art. 15 din L: 554/ 2004 a contenciosului administrativ.

Dincolo de soluțiilejurisprudențiale amintite, considerăm că esteadmisibilă cererea de suspendare efectelor actului administrativ-fiscal în baza dispozițiilor art. 15, când suspendarea executării actului a fost deja pronunțată în baza dispozițiilor art. 14, cu finalitatea prelungirii efectelor suspensive de executare dincolo de momentul pronunțării instanței pe fondul litigiului, neexistând niciun impediment de ordin imperativ și nici condiția consemnării unei noi cauțiuni.

\footnotetext{
* Asist. univ. dr., Facultatea de Drept a Universităţii Babeş-Bolyai, Cluj-Napoca. Email: septimiuput@law.ubbcluj.ro.

${ }^{1}$ Conform art. 1 pct. 15. C.pr.fisc.
} 
2 Emilia Lucia CĂTANă, Contenciosul actelor administrative asimilate, Ed. C.H. Beck, București, 2017, p. 355.

3 Dacian Cosmin Dragoș, Procedura contenciosului administrativ, Ed. All Beck, București 2002, p. 545.

4 Ilie Iovănaș, Drept administrativ, Ed. Servo Sat, Arad, 1997, p. 54.

${ }^{5}$ Bernard PACTEAU, Contentieux administratif, Presses Universitaires de France, p. 273.

${ }^{6}$ Antonie Iorgovan, Noua lege a contenciosului administrativ. Geneză şi explicații, Ed. Roata, București 2004, p. 333.

${ }^{7}$ Ovidiu PODARU, Drept administrativ. Curs universitar. Actul administrativ, Ed. Hamangiu, București, 2010, p. 340.

${ }^{8}$ Decizia civilă nr. 442 a Înaltei Curți de Casație și Justiție din 30 ianuarie 2013.

${ }^{9}$ C. Ap. Cluj, secția a II-a civilă, de cont. adm. și fisc., înch. din 18 ianuarie 2013.

${ }^{10}$ Legea nr. 207/2015 privind Codul de procedură fiscal a fost publicată în M.Of. nr. 547 din 23 iulie 2015 și a intrat în vigoare la data de 1 ianuarie 2016.

${ }^{11}$ Cosmin Flavius Costaș (coord.), Codul de procedură fiscală. Comentariu pe articole, Ed. Solomon, București, 2016, p. 600.

${ }^{12}$ Sentința civilă nr. 416/2016 a Curții de Apel Cluj.

13 Hotărârea Curții de Justiție a Uniunii Europene din 9 noiembrie 2017, ECLI:EU:C:2017:843.

${ }^{14}$ Sentința civilă nr. 410/2016 a Curții de Apel Cluj.

${ }^{15}$ Cosmin Flavius CosTaȘ, op.cit., p. 601.

16 Potrivit art. 156 C.pr.fisc., Termenele de plată: „a). dacă data comunicării este cuprinsă în intervalul 1-15 din lună, termenul de plată este până la data de 5 a lunii următoare, inclusiv;

b). dacă data comunicării este cuprinsă în intervalul 16-31 din lună, termenul de plată este până la data de 20 a lunii următoare, inclusiv".

${ }^{17}$ Decizia civilă nr. 4947 a ICCJ din 11 aprilie 2013.

${ }^{18}$ Sentința civilă nr. 416/2016 a Curții de Apel Cluj.

${ }^{19}$ Sentința civilă nr. 293/2017 a Curții de Apel Cluj.

20 Sentința civilă nr. 295/2017 a Curții de Apel Cluj.

${ }^{21}$ Cauțiunea ar fi datorată doar, dacă nu, s-ar fi plătit anterior o cauțiune cu privire la o cerere formulată în temeiul dispozițiilor art. 14!

22 În legătură cu excepția nelegală potrivit căreia pe perioada suspendării actului administrativ-fiscal ar curge totuși majorări de întârziere de $0,5 \%$ exclusiv în cazul sumelor datorate bugetelor locale, a se vedea dezvoltările operate de Cosmin Flavius Costaş, în op.cit., p. 604.

${ }^{23}$ Introdus prin Ordonanța Guvernului nr. 30/2017 publicată în M.Of. nr. 708 din 31 august 2017 și intrată în vigoare la data de 3 septembrie 2017.

${ }^{24}$ Reglementarea normativă nu face decât să confirme opinia noastră anterioară elaborării alin. (6) al art. 278 C.pr.fisc. privind inexistența obligativității consemnării unei noi cauțiuni judiciare. .

${ }^{25}$ Totuşi, cererea de suspendare fundamentată pe dispozițiile art. 15 din L: 554/2004 ar putea fi respinsă ca fiind rămasă fără obiect, dacă instanța ar admite cererea de chemare în judecată în contencios fiscal și ar desființa decizia de soluționare a contestației și actul administrativ-fiscal, potrivit unei logici elementare că un act juridic anulat nu mai poate fi suspendat. 